\title{
Marital Privileges and the Right To Testify
}

In the twentieth century there has been an increasing recognition that the married woman can be not only a partner in marriage, but also a partner in crime. As a defendant, she of course has the universally recognized right to testify in her own behalf. ${ }^{1}$ If, however, she has been indicted with her husband on the same or similar criminal charges, her right to testify in her own behalf may conflict with her husband's privilege to exclude adverse spousal testimony or his privilege to exclude testimony which reveals the content of confidential communications he has made to her. Resolution of this conflict is particularly important when the wife is charged with a conspiratorial or accessorial role, since little more than the natural inferences which arise from the marital relationship-close association with her husband and knowledge of his acts-may be sufficient to sustain a conviction; the overt act of aid might easily be found in the everyday acts incident to marriage. ${ }^{2}$ This conflict could also arise when the husband seeks to testify in his own behalf; ${ }^{3}$ the focus of this comment on the wife's problem is solely for the sake of clarity. The purposes of this comment are to explore the ways of resolving the conflict in those jurisdictions in which such a conflict is possible and to suggest that granting separate trials is the most satisfactory solution.

Most states have placed restrictions upon the ability of a wife to offer testimony which is adverse to her husband. The most complete

12 Wigmore, EVIDENCE \& 579 (3d ed. 1940).

2 In recognizing this problem, Chief Justice Traynor of the Supreme Court of California has emphasized that: "[C]ourts still have the responsibility to guard against applying" the law of conspiracy to a wife solely on the ground that she has acted without compulsion. There may be situations where a wife is aware of her husband's illegal activity and even passively helpful to him in the everyday acts incident to marriage. Nevertheless she is not a conspirator unless her actions amount to active participation transcending acts that 'would technically be sufficient to involve her in a criminal conspiracy with him, but which might be far removed from the arm's-length agreement typical of that crime." " People v. Pierce, 61 Cal. 2d 879, 882, 40 Cal. Rptr. 845, 847 (1964), quoting in part from United States v. Dege, 364 U.S. 51, 57-58 (1960) (Warren, C.J., dissenting).

3 See State v. Pickles, 46 N.J. 542, 218 A.2d 609 (1966), where the court held that it was possible that the husband really did not know that his child had been burned or that his wife had caused and later neglected the injuries; separate trials were ordered to permit independent consideration of the husband's conduct. 
restriction today is the non-waivable rule that a wife is incompetent to give such testimony. 4 This prohibition stems from the old common law rule, in force at a time when a wife could not be convicted of a crime except under special circumstances, ${ }^{5}$ that she was incompetent to testify for or against her husband. ${ }^{B}$ In many jurisdictions, statutory rules of incompetency have been weakened by decisions that unless the husband makes a timely objection to the competency of his wife's testimony, the prohibition is waived.7 This waiver provision transforms

4 See N.C. Gen. StAT. \& 8-57 (Supp. 1965), State v. Warren, 236 N.C. 358, 72 S.E.2d 763 (1952); Tex. Code Crim. Proc. art. 38.11 (1966), Brock v. State, 44 Tex. Crim. 335, II S.W. 20 (1902), Hagans v. State, 372 S.W.2d 946 (Tex. Crim. App. 1962) (dictum).

5 The wife could be convicted of a crime when she acted alone, or committed murder or treason, or one of certain special offenses such as keeping a brothel. 4 BLAckstone, Commentaries *28-29. The common law approach also made it impossible for the wife to be charged with assisting or conspiring with her husband in criminal endeavors.

A number of jurisdictions still provide the married woman a measure of immunity from criminal prosecution by maintaining a presumption of marital coercion-a wife who commits a crime with her husband is presumed to be acting under his coercion. See generally Perkins, The Doctrine of Marital Coercion, 29 TEMP. L.Q. 190, 192 (1956). However, in those states, many exceptions to the presumption, other than those crimes which the common law excepted, have been introduced by statute. See, e.g., OkLA. STat. ANN. tit. 21, § 157 (1958). (e.g., maiming, seduction, child abuse, abortion, bigamy, obscene exhibition of books). Some courts have held the presumption to be so weak as to be rebuttable by slight proof. E.g., United States v. Anthony, 145 F. Supp. 323 (M.D. Pa. 1956) (dictum). Some state legislatures have abolished the presumption. E.g., ILL. REv. STAr. ch. 38, \& 7-II (1963); N.Y. PEN. LAW § 1092. In other states the doctrine has been abolished judicially. E.g., State v. Renslow, 211 Iowa 642, 230 N.W. 316 (1930); King v. City of Owensboro, 187 Ky. 21, 218 S.W. 297 (Ct. App. 1920). See generally Note, The Effect of Marriage on the Rules of the Criminal Law, 61 CoLuM. L. REv. 73 (1961).

The impact of this evolution of the married woman's criminal responsibility is most apparent in the area of criminal conspiracy. Although it had often been held under the common law that a wife could be indicted with her husband for conspiracy when a third person was involved, the theory of the unity of husband and wife usually prevented an indictment of the husband and wife alone. See, e.g., Gros v. United States, 138 F.2d 261 (9th Cir. 1943); People v. Miller, 82 Cal. 107, 22 Pac. 934 (1889); Commonwealth v. Allen, 24 Pa. County Ct. 65 (1900). Contra, Johnson v. United States, 157 F.2d 209 (D.C. Cir. 1946); Dalton v. People, 68 Colo. 44, 189 Pac. 37 (1920). Generally this conspiracy doctrine persisted longer than the rule prohibiting criminal prosecution of the wife, but in recent years it has been substantially eroded. See, e.g., United States v. Dege, 364 U.S. 51 (1960), overruling Gros v. United States, supra; People v. Pierce, 61 Cal. 2d 879, 40 Cal. Rptr. 845 (1964), overruling People v. Miller, supra. But see State v. Struck, 44 N.J. Super. 274, 129 S.2d 910 (Essex County Ct. 1957).

6 At common law, exceptions were made in cases of absolute necessity, as when a husband was accused of a crime against his wife's person. See, e.g., State v. Neill, 6 Ala. 685 (1844). The wife was competent to testify for her husband in certain other matters. See, e.g., Littlefield v. Rice, 51 Mass. (10 Met.) 287 (1845) (involving accuracy of account books kept by wife under husband's direction); McGill v. Rowand, $3 \mathrm{~Pa}, 451$ (1846) (involving proof of the contents of a trunk, on the theory that a wife usually packs for her husband).

7 See State v. Houston, 50 Iowa 512 (1879), interpreting IowA CODE ANN. \$ 622.7 (1950); Huff v. State, 176 Miss. 443, 169 So. 839 (1936), interpreting Miss. Code ANN. $\$ 1689$ (1942); 
the incompetency rule into the husband's more familiar privilege to exclude his wife's adverse testimony.

There were several rationales for the old rule of incompetency. Courts were reluctant to risk placing a wife in the position of having to choose between her duty to testify truthfully and her duty to provide aid and comfort to her husband. ${ }^{\text {T }}$ There was also fear of producing marital disharmony if the wife's testimony were unfavorable to her husband. ${ }^{9}$ Most often it was said that her testimony was likely to depend upon her feelings toward her spouse ${ }^{10}$ or, more important, that her own interests as a wife were too closely tied to those of her husband to trust her testimony. ${ }^{11}$ In short, it was thought that her testimony was so likely to be untrustworthy that as a general rule it ought not to be admitted.

The contemporary justification for the privilege to exclude adverse spousal testimony was stated by Mr. Justice Black, speaking for the Court in Hawkins $v$. United States: ${ }^{12}$

The basic reason the law has refused to pit wife against husband or husband against wife in a trial where life or liberty is at stake was a belief that such a policy was necessary to foster family peace, not only for the benefit of the husband, wife, and children, but for the benefit of the public as well. Such a belief has never been unreasonable and is not now. ${ }^{13}$

It has been said by critics of the testimony privilege that it is nothing more than an anachronism inhibiting full disclosure of all relevant facts; ${ }^{14}$ that if the wife is willing to volunteer testimony there may be little harmony left to preserve. Mr. Justice Black gave this answer:

Ruch v. State, 111 Ohio St. 580, 146 N.E. 67 (1924), interpreting OHIo REv. Code ANN. \$ 2954.42 (Baldwin 1964); Commonwealth ex rel. Haines v. Banmiller, 19 Pa. D. \& C.2d 219 (1959) affd, 398 Pa. 7, 157 A.2d 167 (1959), cert. denied, 363 U.S. 807 (1960), interpreting Pa. Stat. AnN. tit. 19, § 683 (1964); Bernell v. State, 74 Okla. Crim. 92, 101, 123 P.2d 289, 293 (1942) (dictum), interpreting OKLA. Stat. ANN. tit. 22, § 702 (Supp. 1965).

8 Kelly v. Proctor, 41 N.H. 139 (1960).

9 Ibid.

102 Wigmore, EVIDENCE § 601, at 732 (3d ed. 1940).

$11 \mathrm{Id}$. at 731. See also Jin Fuey Moy v. United States, 254 U.S. 189 (1920), overruled, Funk v. United States, 290 U.S. 371, 387 (1933).

12358 U.S. 74 (1958). This case upheld the privilege in the federal courts.

$13 \mathrm{Id}$. at 77. For a general discussion of the marital privileges in the federal courts see Orfield, The Husband-Wife Privileges in Federal Criminal Procedure, 24 OHo ST. L.J. 144 (1963).

14 See, e.g., Hawkins v. United States, 358 U.S. 74, 81 (1958) (Stewart, J., concurring); UNIFORM Rule of Evidence 23, comment; Committee on Improvements in the Law of Evidence, Report, 63 REPORTS OF tHE ABA 570, 594-95 (1938); 8 Wigmore, Evidence $\S 2228$, at 221 (McNaughton rev. 1961). 
But not all marital flare-ups in which one spouse wants to hurt the other are permanent. The widespread success achieved by the courts throughout the country conciliating family differences is a real indication that some apparently broken homes can be saved provided no unforgivable act is done by either party. Adverse testimony given in criminal proceedings would, we think, be likely to destroy almost any marriage. ${ }^{15}$

But if a wife has been indicted with her husband and is in danger of losing her life or her freedom, then perhaps the danger of doing irreparable harm to the marriage by permitting her to testify loses its importance by comparison. Furthermore, her husband's refusal to permit her to exculpate herself is likely to be as destructive of the marriage as anything she might say against him.

In a number of jurisdictions restrictions on adverse testimony have been limited by allowing only the wife, as a witness, to invoke a privilege to refuse to render such testimony, ${ }^{16}$ apparently on the theory that the wife should be permitted to determine for herself whether her marriage can or should be saved by her refusal to testify. ${ }^{17}$ Several other jurisdictions, apparently heeding the arguments of the critics of the testimonial privilege, have completely abolished it. ${ }^{18}$ In these, there remain restrictions only on the wife's testimony concerning her husband's confidential communications. The most common of these is the husband's privilege to exclude his wife's testimony as to the confidential communications made to her during their marriage. ${ }^{19}$ As with the

16 Hawkins v. United States, 358 U.S. 74, 77-78 (1958).

16 See Ala. Code tit. 15, \& 311 (1958); Calm. Evid. Code \$ 970 (effective Jan. 1, 1967); Conn. Gen. Stat. Ann. \& 54-84 (1958); D.C. Code ANN. tit. 14, \& 306 (Supp. V 1966); GA. Code ANN. § 38-1604 (Supp. 1965); Ky. Rev. StAt. ANN. § 421.210 (1963); LA. Rev. Stat. ANn. \& 15:461 (1950; Md. ANN. CodE art. 35, § 4 (1957); MAss. ANn. LAws ch. 233, \& 20 (Supp. 1965).

17 See Note, 38 VA. L. REv. 359 (1952), favoring this rule.

18 See State v. Lynch, 32 Del, 600, 128 Atl. 565 (1925) (dictum), interpreting Del. Code ANN. ch. 11, § 3502 (1953); Ex parte Beville, 58 Fla. 170, 50 So. 685 (1909), and Porter v. State, 160 So. 2d 104 (Fla. Sup. Ct. 1963), cert. denied, 379 U.S. 849 (1965), interpreting Fla. Stat. AnN. § 90.04, 932.31; ILl. Rev. Stat. ch. 38, § 155-1 (1965); Kan. Gen. Stat. ANN. § 60-423 (1963), adopting Uniform Rule of Evidence 23; ME. Rev. Stat. AnN. tit. 15, $\S 1315$ (1964); N.H. Rev. StAT. ANN. ch. 516, \& 27 (1955); N.X. PEN. LAW § 2445; S.C. Code ANN. § 26-403 (1962); VT. StAT. ANn. tit. 12, \& 1605 (1958).

19 See, e.g., ARIz. Rev. StAT. ANn. $\$ 13-1802$ (Supp. 1966); CAL. Evm. Code $\$ 980$ (effective Jan. 1, 1967); IdAHo CoDE ANN. 1947 \& 9-203 (Supp. 1965); LA. Rev. Stat. ANN. \& 15:461 (1950); Mich. StAT. ANN. § 27A.2162 (1962); MinN. StAT. ANN. § 595.02 (1945); Miss. CodE ANN. § 1689 (1942); Mont. Rev. Codes ANN. § 93-701-4 (1947); Nev. Rev. Stat. § 48.040 (1957); N.Y. PEn. LAw § 2445; PA. Stat. ANn. tit. 19, § 684 (1964); Utah COde ANN. § 78$24-8$ (1953); VT. Stat. ANN. tit. 12, § 1605 (1958); VA. Code ANN. \& 8-289 (1950).

Some states have broadened the scope of the privilege by holding that acts are com- 
testimonial privilege, there are variations phrased in terms of competency, ${ }^{20}$ with a number of states adopting a waiver rule, ${ }^{21}$ or giving the privilege to the witness alone. ${ }^{22}$

The communications privilege is generally supported on the theory that knowledge by the spouses that their confidential communications to each other will not be disclosed in court helps to foster an intimate, harmonious relationship; that the possibility of future disclosures "might cast a cloud upon an essential aspect of the institution of marriage" 23 and cause greater injury to that institution than the benefit which society would derive from the breach of a confidence at a trial. ${ }^{24}$ However, critics of the communications privilege have observed that there are so few persons outside the legal profession who are aware of the privilege that it seems doubtful that knowledge that confidential communications cannot later be disclosed in court has significantly encouraged free and open communication between spouses. ${ }^{25}$ Perhaps a better explanation for the privilege is that it is a response to natural, emotional feelings that prying into the intimacies of the marital rela-

munications. See, e.g., People v. Daghita, 299 N.Y. 194, 86 N.E.2d 172 (1949) (wife's knowledge gained by observing her husband hiding stolen property in their home was the result of a confidential communication; he would never have so conducted himself except in reliance upon the privacy of the marital relationship); Menefee v. Commonwealth, 189 Va. 900, 55 S.E.2d 9 (1949) (divorced wife could not testify that she drove her husband to the place where a stolen safe had been buried and that she had seen him come home with a revolver on the night of the crime); French v. Ware, $65 \mathrm{Vt}$. 338, 26 Atl. 1096 (1893) (dictum).

20 See, e.g., Md. ANN. Code art. 35, § 4 (1957); Mass. ANn. Laws ch. 233, § 20 (1956); NEB. REv. STAT. § 25-1204 (Supp. 1964); N.H. REv. StAT. ANN. § 516:27 (1955).

21 See, e.g., GA. CODE ANN. § 38-418 (Supp. 1965), Holloway v. Hoard, 140 Ga. 380, 78 S.E. 928 (1913); IOWA CoDE ANN. \& 622.9 (1946), Crowell v. Northwestern Nat. Life Ins. Co., 140 Ia. 258, 118 N.W. 412 (1908); Mo. ANN. STAT. \$ 546.260 (1949), State v. Hill, 76 S.W.2d 1092 (Mo. 1934); TEx. Code CriM. Proc. ANN. art. 38.11 (1966), Johnson v. State, 95 Tex. Crim. 483, 255 S.W. 416 (1923); Vr. Stat. ANN. tit. 12, \& 1605 (1958), State v. Bell, 119 Vt. 306, 126 A.2d 121 (1956).

22 See, e.g., HawaII Rev. Laws § 222.19 (1955); N.M. Stat. ANn. § 20-1-12 (1953); R.I. GEN. LAws ANN. § 9-17-13 (1956), as interpreted by State v. Kenyon, 18 R.I. 217, 26 Atl. 199 (1893).

238 Wigmore, Evidence $\S 2332$, at 643 (McNaughton rev. 1961). See Comment, The Husband-Wife Privileges of Testimonial Non-disclosure, 56 Nw. U.L. REv. 208, 231 (1961).

24 Louisell, Confidentiality, Conformity, and Confusion: Privileges in Federal Court Today, 31 Tux. L. Rev. 101, 113 (1956); see 8 Wigmore, EvtDENcE $\S 2285$ (McNaughton rev. 1961).

25 Hines, Privileged Testimony of Husband and Wife in California, 19 CaLIF. L. Rev. 390, 413 (1931); Hutchins \& Slesinger, Some Observations on the Law of Evidence: Family Relations, 13 MINN. L. REv. 675, 682 (1929). But if the communications privilege were now to be abolished, publicity about the change might reach large segments of the population of a state. One might then expect a decrease in communication between spouses swich could lead to marital disharmony. 
tionship is an act of indelicacy which a court ought not to commit. ${ }^{26}$ It may, however, be a greater act of indelicacy to refuse to allow a wife to offer exculpatory testimony and perhaps permit a conviction simply to preserve the confidentiality of her husband's statements. ${ }^{27}$

Of course the conflict between the wife's right to testify and her husband's exclusionary privileges cannot arise in those states which have abolished the privileges entirely or which have given them to the witness alone. But in those states which retain either privilege in any of the other forms described above, the conflict is a real possibility. How serious the problem is may depend upon the circumstances of the individual case, since courts are likely to attempt to define narrowly the scope of adversity or confidentiality. ${ }^{28}$

The conflict between the wife's right to testify and her husband's exclusionary privilege could be resolved in one of three ways. One solution would be to eliminate the wife's right in cases of conflict. This proposal can be rejected since it would seem improper either to be concerned with marital harmony when the wife's life or freedom is at stake, or to respect the intimacy of the husband's communication to his wife when to do so would permit him to deprive her of an opportunity to exculpate herself.

The second general approach would involve restricting the husband's privileges. Total abolition is, of course, too broad a solution to be used simply to protect the wife in cases of conflict. A variation would be to emulate those states which have given the testimony or communications privilege to the witness spouse alone by adopting that rule for both" privileges. Again, however, the solution seems to be broader than the problem since the wife would be able to offer testimony at trials in which she were not a defendant and, therefore, would have no pressing need to introduce evidence concerning her husband's acts or communications. A more limited approach, like that followed in Kentucky for confidential communications, ${ }^{29}$ would be to abolish

26 MCCORMICK, EvmeNCE § 90 (1954); Comment, supra note 28, 56 Nw. U.L. REv. at 212. 27 MCGORMICK, EVIDENCE $\$ 90$ (1954).

28 See, e.g., People v. Palumbo, 5 Ill. 2d 409, 125 N.E.2d 518 (1955) (presence of third person negated any inference that the communication was intended to be confidential; statute makes no reference to third person).

29 See Gill v. Commonwealth, 374 S.W.2d 848 (Ky. Ct. App. 1964). In that case a wife, being jointly tried with another woman for armed robbery, objected to her husband's testimony as to certain alleged confidential conversations which they had had regarding the offense. The husband had previously been tried and convicted of the same crime and was appearing as a witness for the prosecution. The Court of Appeals of Kentucky held that the confidential communications privilege did not cover conversations with respect to criminal acts allegedly committed by a husband and wife. Although no interest of the husband was protected by permitting him to testify, the court applied a limited 
the privileges whenever a husband and wife are jointly indictedwhether or not jointly tried-for a crime. However, this rule also seems too broad since its effect is not to protect the wife in cases of conflict but merely to tempt prosecutors to breach the confidence and harmony of the marriage in order to secure a conviction.

What might be more desirable than these broad limitations upon the husband's privileges would be a simple rule which would permit the wife's right to testify to prevail over her husband's exclusionary privileges. This appears to be the result which will be obtained with regard to confidential communications under section 987 of California's new Evidence Code:

There is no privilege under this article in a criminal proceeding in which the communication is offered in evidence by a defendant who is one of the spouses between whom the communication was made.

This section is taken from the less precisely worded Uniform Rule of Evidence 28(2)(d). The rule provides that neither spouse may claim the communications privilege "in a criminal action in which the accused offers evidence of a communication between him and his spouse." This apparently means that if an accused spouse offers testimony as to a confidential communication, neither he nor his codefendant spouse will be able thereafter to invoke the privilege as to that communication. Rule $28(2)$ (d) is, however, susceptible to a broader interpretation: an accused spouse has the option to dissolve the communications privilege entirely by offering evidence as to one communication between the spouses. Thereafter, the privilege would not apply during the trial to any other, though unrelated, communication which either might wish to keep secret. The rule would thus be similar to a rule of total abolition of the communications privilege in joint or separate trials except that this rule would apply only if activated by an accused spouse. The latter interpretation of rule 28(2)(d) seems unjustifiably broad and was probably not the intention of the drafters. ${ }^{30}$ California Evidence Code section 987 and Uniform Rule 28(2)(d) are variations on Professor Wigmore's suggested exception to the com-

dissolution rule because it felt that the communications privilege should not protect the spouses in their criminal endeavors. See Louisell, supra note 24, at 104. See also UNIFORM RULE OF EvIDENCE 28(2)(e), discussed infra note 45.

30 Quick, Privileges under the Uniform Rules of Evidence, 26 U. CrN. L. Rxv. 537, 553 (1957). One other interpretation of rule 28(2)(d) is possible: in view of the use of the definite article "the" in "the accused," it is quite possible that the rule only applies when one of the spouses has been indicted. Compare CAC. Evid. Cone $\$ 987$ (effective Jan. 1,1967 ). If so, then only rule $28(2)(e)$ would be at all relevant, although it seems to apply only when a conspiracy can be established by other evidence. See note 45 infra. 
munications privilege: ${ }^{31}$ "[W] here an accused spouse needs the evidence of communications (by either spouse to the other), the privilege should cease or a cruel injustice may be done." 32

Only a few states have adopted a rule of limited dissolution of the husband's privileges. One state, Kansas, has adopted the Uniform Rules of Evidence, ${ }^{33}$ which abolish the adverse testimony privilege, ${ }^{34}$ but there are no reported cases applying rule 28(2)(d). California, whose new evidence code goes into effect on January 1,1967 , has given the adverse testimony privilege to the witness ${ }^{35}$ and has provided the exception noted above for confidential communications. ${ }^{36}$ Texas has adopted a rule similar to the Wigmore suggestion with regard to confidential communications, although the adverse testimony restriction remains. ${ }^{37}$ Again, there are no reported cases applying the rule. Finally, Kentucky has adopted the broad rule discussed above which abolishes the confidential communications privilege in cases of joint indictments. $^{38}$

Limited dissolution will solve the basic conflict without destroying the whole marital privilege system. Furthermore, the theory that public policy may occasionally require limitations on privileges is at present accepted in most, if not all, states. Even states which make the wife totally incompetent to testify against her husband have provided exceptions where he is charged with a crime against her person, or with abandonment of a wife or child. ${ }^{30}$ Similarly, exceptions to the various restrictions on the disclosure of confidential communications have been introduced to aid in the enforcement of the husband's legal obligations in cases of abandonment and non-support; ${ }^{40}$ and in Mann

31 Wigmore's suggestion is apparently considered by some to be the direct ancestor of rule 28(2)(a). See 8 WIGMORE, EvIDENCE $\S 2338$, at 666 n.3 (McNaughton rev. 1961); Model Code of EVIDENCE rule 216, comment (1942), cited in UnIform RULe of EVIDENcE 28, comment.

328 Wigmore, Evidence $\S 2338$, at 666 (McNaughton rev. 1961); cf. TEX. Code CrM. Proc. ANN. art. 38.11 (1966).

33 KAN. Gen. StAT. ANN. $\S 80-401$ to 469 (1963). New Jersey has adopted a modified version of the Uniform Rules of Evidence but without the exceptions in rule 28. See N.J. Stat. ANN. \& 2A: 84A-22 (Supp. 1965).

34 UNIFORM RULE OF EVIOENCE 23.

35 CAL. Evid. CODE § 970 (effective Jan. 1, 1967).

36 The official comment to section 987 recognizes that the section introduces a new concept into California evidence law.

37 See TEx. Code Crim. Proc. ANN. art. 38.11 (1966), and text accompanying note 4 supra. 38 See note 45 infra and text accompanying note 29 supra.

30 See N.G. Gen. Stat. § 8-57 (Supp. 1965); Tex. Code Crum. Proc. Ann. art. 38.11 (1966).

40 See Unifordy Desertion and Nonsupport Act $\S 6$ (23 states). See also Uniform RECIPROCAL ENFORCEMENT OF SUPPORT ACT $\$ 22$ (1952) (32 states); UNIFORM RECIPROCAL ENFORCEMENT OF SUPPORT ACT § 25 (1958) (15 states). 
Act prosecutions, to keep the alleged offender from silencing his "victim" by marrying her, the defendant's wife can be compelled to testify regardless of the effect upon her husband if in fact she was the woman transported across state lines for purposes of prostitution. ${ }^{41}$ Permitting the wife to testify in order to exculpate herself would seem to be at least as strong a justification for limiting her husband's exclusionary privileges as any which could be advanced in favor of the present exceptions. But there are costs in implementing a rule of limited dissolution which detract from its desirability.

One defect common to all of the rules of limited dissolution is that although the wife's ability to offer a reasonable defense will improve if she is permitted fully to testify in her own behalf, the jury may have an unfavorable reaction to a wife whose testimony seems designed to exonerate herself at the expense of her husband who is on trial with her. ${ }^{42}$ Even severance will not completely solve the problem, but it does reduce its potential effect by permitting a jury to decide upon the guilt of one person only; acceptance of the wife's defense by the jury at her trial will not automatically mean conviction of the husband at his.

Another potential difficulty, which applies equally to giving control over a privilege to the witness or to the accused, as in section 987 of the California Evidence Code and rule 28(2)(d), or dissolving the privileges outright in instances of joint indictments, is that such rules invite abuse by overzealous prosecutors. If the prosecutor thinks the wife has knowledge of her husband's activities, he may cause her to be indicted with her husband regardless of whether he suspects her of complicity. The intimacy of the marital relationship could easily produce the inference of complicity and the wife, fearing conviction for a crime she did not commit, might offer testimony which would convict her husband. The mere fact that under these circumstances her testimony might be voluntary would be no indication that her marriage was no longer harmonious. It might only mean that the prosecutor had induced her to destroy her marriage in order to save herself. There is also the danger that the wife might prefer to keep silent, in which case she might be unjustly convicted as a result of her loyalty to her husband.

A serious defect in emulating Professor Wigmore's suggested exception to the communications privilege is that it may be extremely diff-

41 Wyatt v. United States, 362 U.S. 525 (1959).

42 Such a situation was thought likely to occur in reverse in State v. Pickles, 46 N.J. 542, 218 A.2d 609 (1966), where the court thought that the jury might react unfavorably to the husband's attempt to cast blame upon his wife for the death of their son through neglect of the child's burns; severance was granted. 
cult for a trial judge to make a prospective determination of "need"that is, the importance of the wife's testimony to her defense.43 For example, if the wife, in the course of attempting to establish that she did not participate in a robbery, declares that her codefendant spouse told her that he had just held up a store, the judge will not only have to determine the relevance of the remark to her defense but also, assuming relevancy, the probability that exclusion of the statement will prevent her from offering to the jury a credible defense. Whichever party is adversely affected by his ruling will, if convicted, raise the issue on appeal and in close decisions the chances for reversal and retrial are likely to be quite high. Furthermore, for the rule to be administered properly the trial judge would have to hear the testimony to be offered by the wife outside the presence of the jury to be certain that they did not hear statements by the wife which were not essential to her defense but which would be damaging to her husband. ${ }^{44}$ In instances where the wife is seeking to establish a defense which conflicts with that of her husband, such as coercion, her husband's defense counsel may be forced to raise numerous objections to her testimony each of which would require the judge to leave the courtroom or excuse the jury so that he might hear her testimony and evaluate its probable impact in relation to her total defense. The result would be both time consuming and disruptive. Furthermore, the jury might become suspicious of the interruptions and begin to draw inferences adverse to the husband; or the husband's attorney, fearing such inferences, might feel constrained to avoid making some objections which he ought properly to make.

The strength of the California Evidence Code and the Uniform Rules of Evidence is that they do not pose a similar evaluative problem: the wife's testimony as to her husband's confidential communications is limited only by the general requirements of relevance which are imposed upon the testimony of any witness. Yet this strength is also a weakness. Since the trial judge has little or no discretion to exclude the wife's testimony, he must allow the wife to testify even when her evidence will have little effect upon her own fate. For example, if

43 Cf. Tex. Code Cring. Proc. Ans. art. 38.11 (1966), apparently requiring the trial judge to determine whether the content of the communication to be revealed will "extenuate or justify the offense."

44 For example, if the wife, in attempting to prove that she had not aided her husband in the commission of an armed robbery by driving the getaway car, testifies that on the day following the robbery her husband had told her that he had solved their money problems the previous day, the effect would undoubtedly be to incriminate the husband in the eyes of the jury despite the questionable relevance of the statement to the wife's defense and despite instructions by the court to disregard it. 
the state has produced little or no evidence to sustain a conviction or the wite or it the other evidence against her is absolutely conclusive of her guilt, testimony as to details of the crime, which her husband allegedly revealed to her, would not aid her but would only serve to convict her husband. The Kentucky rule would seem to be subject to the same criticism. ${ }^{45}$ It suffers from the further defect that the rule applies even when the spouses are being tried separately although the wife has no need to offer the testimony at her husband's trial. Clearly these rules, which permit the wife to reveal confidential communications without regard to the importance of the testimony to her own defense, are at odds with the law's normal reluctance to pry into the confidentiality of a marriage except for strong reasons.

The third general approach would be for the trial judge to grant severance either automatically on the motion of either accused spouse or, as is now done, whenever it appears that at a joint trial the wife's right to testify would conflict with her husband's exclusionary privileges. Severance is clearly the practical alternative to limited dissolution of the husband's privileges, but its use is not barred in those states which now permit limited dissolution.

The attractiveness of severance stems at least in part from the fact that it avoids the conflict between the wife's right to testify and her husband's exclusionary privileges by eliminating the situation in which it arises-the joint trial. Furthermore, the trial judge's task in deciding whether there would actually be a conflict at a joint trial sufficient to require severance is eased considerably by the knowledge that in a

45 See Gill v. Commonwealth, 374 S.W.2d 848 (Ky. Ct. App. 1964), discussed supra note 29.

Uniform Rule of Evidence 28(2)(e) escapes this criticism at the cost of posing another evaluative problem. The rule states that neither husband nor wife can claim the communications privilege "if the judge finds that sufficient evidence, aside from the communication, has been introduced to warrant a finding that the communication was made, in whole or in part, to enable or aid anyone to plan to commit a crime or a tort." This seems to contemplate a conspiracy or concerted action and may be of no help at all to an innocent wife; the mere fact that the disclosure of a communication exculpates her may negate the validity of the finding that the communication aided the commission of a crime. See CAL. Ev. CODE $\$ 981 \&$ comment. In any event, the trial judge's determination that there was or was not "sufficient evidence, aside from the communication" could prove to be a continual source of appeals.

Two old Texas cases, which are probably superseded by Tex. Cone Crim. Proc. ANN. art. 38.11 (1966), have been cited as standing for the proposition that "when husband and wife are coconspirators, or when the evidence justifies such a conclusion, a declaration of the husband or wife at the time of the act is not privileged." 97 C.J.S., Witnesses $\S 269$, at 773, citing Goforth v. State, 100 Tex. Crim. 442, 273 S.W. 845 (1920), and Thompson v. State, 77 Tex. Crim. 417, 178 S.W. 1192 (1915). However, in both cases the communications were made in the presence of third parties who testified as to their contents. The proposition has not been cited as authority for a decision after Goforth, but recently, in Gill v. Commonwealth, supra at 851, the Kentucky Court of Appeals cited it as authority for the rule of limited dissolution laid down in that case. 
close case granting a motion for severance is not likely to be charged as error by either defendant. Any risk to the marriage posed by the wife's testimony is substantially reduced because testimony given by her at her own trial could clearly be excluded by her husband at his trial if covered by his exclusionary privileges ${ }^{46}$ and could thus have no direct effect upon his fate. ${ }^{47}$ This same reason reduces the incentive for the prosecutor to press a spurious indictment of the wife since she could avoid testifying adversely to her husband by obtaining a separate trial. Finally, as noted above, severance reduces the possibility that the jury might react unfavorably to what might appear to be an attempt by one spouse to get the jury to convict only the other.

One difficulty with severance as a solution is that, as administered today, its granting is purely discretionary and is usually said to be available only upon a prospective determination by the trial judge that there is a high probability that one of the codefendants at a joint trial will be prejudiced by the defense offered by the other. ${ }^{48}$ Severance is therefore not available as a matter of right, ${ }^{49}$ and a decision denying severance will not be reversed unless the trial judge has clearly abused his discretion. ${ }^{50}$ What apparently lies behind the restricted application of severance is a recognition that, especially in conspiracy cases where it is desirable to have all of the defendants together before a jury, separate trials are more difficult to prosecute, and are more expensive and time consuming than a joint trial.51 Thus, severance is likely

46 State v. Turnbow, 67 N.M. 241, 354 P.2d 533 (1960).

47 If the husband is tried first, then there is no danger whatever that he could be harmed by any information his wife might divulge. See Ayres v. State, 105 Tex. Crim. 15, 284 S.W. 960 (1926).

48 See, e.g., State v. Hunt, 2 Ariz. App. 6, 406 P.2d 208 (1965). But see State v. Cotton, 218 N.C. 577,12 S.E.2d $246(1940)$. Some courts state that the trial judge has an obligation throughout a trial to grant severance whenever it appears that one defendant has been prejudiced by joinder with a codefendant. See, e.g., United States v. Kelly, 349 F.2d 720 (2d Cir. 1965); State v. Nutley, 24 Wisc. 2d 527, 129 N.T.2d 155 (1964). It is possible that most appellate courts would reverse a denial of a motion for severance based upon a reasonable prospective evaluation of the evidence to be presented if it turned out that one defendant had been severely prejudiced by joinder with his codefendants. See, e.g., State v. Pickles, 46 N.J. 542, 218 A.2d 609 (1966). But pronouncements in cases like Hunt would indicate that for many courts the prejudice must be shown to have been quite severe.

49 But see W. VA. Code ANN. $\S 6197$ (1961). This statute is interpreted to entitle a defendant to a separate trial if he so elects. State ex rel. Zirk v. Muntzing, $146 \mathrm{~W}$. Va. 349, 120 S.E.2d 260 (1961).

50 See Opper v. United States, 348 U.S. 84 (1954); Peek v. United States, 321 F.2d 934 (9th Cir.), cert. denied, 376 U.S. 954 (1963); United States v. Lebron, 222 F.2d 531 (2d Gir.), cert. denied, 350 U.S. 876 (1955); State v. Hunt, 2 Ariz. App. 6, 406 P.2d 208 (1965). See also Annot., 54 A.L.R.2d 830 (1957), for scores of cases from many jurisdictions adhering to this rule.

51 United States v. Andreadis, 238 F. Supp. 800 (D.C.N.Y. 1965). But see State v. Turnbow, 67 N.M. 241, 354 P.2d 533 (1960) (McGhee, C.J.); People v. Krugman, 44 
to be granted only when the defense of one accused person will be clearly prejudiced by joinder with his codefendants at a single trial. ${ }^{62}$ Yet if severance is to be an effective solution here, it ought to be available automatically upon the motion of either accused spouse. The judge's instructions to the jury to disregard those portions of a wife's testimony which are prejudicial to her husband are inadequate since they will not wash the memory of her words from the minds of the jury. ${ }^{53}$ An automatic severance rule would also avoid the necessity for the trial judge to decide if either the wife's right to testify or the husband's exclusionary privileges might be denied at a joint trial; a conspicuous ground for reversal on appeal would thus be eliminated. For example, in cases in which the wife seeks to establish a defense of nonparticipation in her husband's crimes, much of her testimony will probably clash with her husband's exclusionary privileges. But it may not be possible to determine prospectively the extent of the conflict or the effect of individual rulings by the judge; in retrospect it may turn out that every ruling concerning the admission or exclusion of testimony aided one defendant only at the expense of prejudice to the other. Finally, an automatic severance rule would introduce a consistency which has long been lacking in the case law on severance. ${ }^{54}$

One shortcoming in the use of severance is that it is not entirely clear that the husband could not object to his wife's attempts to reveal confidential communications at her separate trial. If the primary purpose of the communications privilege is the maintenance of marital privacy, then it might follow that a husband could exclude his wife's testimony even though he is not a party to her trial. ${ }^{55}$ Such a result should not be

Misc. 2d 48, 252 N.Y.S.2d 846 (Sup. Ct. 1964) (Sobell, J.). Both Judge McGhee and Judge Sobell condemn the practice of refusing to grant severance solely on the grounds of the speed, economy, or convenience of a single trial. See also Comment, Exercise of the Privilege Against Self-Incrimination by Witnesses and Codefendants: The Effect Upon the Accused, 33 U. CHI. L. REv. 151, 161 (1965).

52 See, e.g., People v. Aranda, 63 C.2d 518, 407 P.2d 265, 47 Cal. Rptr. 353 (1965); State v. Turnbow, 67 N.M. 241, 354 P.2d 533 (1960); People v. Krugman, 44 Misc. 2d 48, 252 N.Y.S.2d 846 (Sup. Ct. 1964).

53 Accord, State v. Green, 46 N.J. 192, 215 A.2d 546 (1965); Smith v. State, 141 Tex. Crim. 577, 150 S.W.2d 388 (1941).

54 Compare People v. Doran, 246 N.Y. 409, 159 N.E. 379 (1927), with People v. Feolo, 282 N.Y. 276, 26 N.E.2d 256 (1940). Although neither case involved codefendant spouses, the cases provide a striking example of the inconsistencies in the application of severance to very similar fact situations.

55 Cf. Commonwealth v. Cleary, 152 Mass. 491, 25 N.E. 834 (1890); see People v. Ernst, 306 Ill. 452, 138 N.E. 116 (1943) (defendant charged with forgery not permitted to testify to wife's statements authorizing him to sign her name); People v. Bowen, 165 Mich. 231, 130 N.W. 706 (1911) (husband charged with murdering his wife not allowed to testify as to her confession of infidelity to him); Steeley v. State, 17 Okla. Crim. 232, 187 Pac. 321 (1920) (husband charged with killing another man not permitted to testify as 
permitted. The husband's privilege should be dissolved at the wife's separate trial so that she may offer exculpatory testimony. Even if the privilege were to be limited only in cases where the husband has already been tried, and thus could not be harmed by his wife's disclosures,, 56 severance still retains its advantages with regard to adverse spousal testimony. Furthermore, in those states which have given the communications privilege to the witness or have adopted a rule of limited dissolution there is certainly no barrier to granting severance and thus no barrier to a wife who wishes to offer testimony at her own trial as to her husband's confidential communications.

An instructive instance of the use of severance to avoid the husband-wife conflict is found in State v. Turnbow.57 Turnbow, his wife Rita, and one Carter were jointly indicted for the murder of a storekeeper during an attempted robbery. At trial, the Turnbows moved for severance on the grounds of mutually antagonistic defenses and conflict between the right of the spouses as defendants to testify and the incompetence of a spouse to render testimony adverse to his mate. Severance was denied. Over Rita Turnbow's objection, extra-judicial statements of James Turnbow were admitted which tended to incriminate his wife. Rita, in attempting to establish the defense of coercion by her husband, testified over his objection to prior instances where he had committed acts of violence against her. The trial judge apparently felt that prejudicial error could be avoided by special instructions to the jury to disregard the evidence of each spouse which was adverse to the other. The Supreme Court of New Mexico held that the denial of the motion for severance and the use instead of special instructions to the jury constituted reversible error on the facts of this case. The court pointed out that here was a clear case of conflict between a spouse's right to testify in his own behalf ${ }^{3 s}$ and the right of the codefendant spouse to exclude that testimony if incriminatory ${ }^{53}$ a conflict which could only be resolved by separate trials:

to statements made by his wife admitting infidelity in order to prove his state of mind); Tingley v. State, 16 OkIa. Crim. 639, 184 Pac. 599 (1919) (same). In each of these cases, the defendant's wife was not on trial nor even charged with an offense. It is difficult to see what interest was being protected, especially in People v. Bowen, supra, where the wife was dead. Wigmore cites these cases as examples of instances where the communications privilege should be dissolved so that the accused spouse may present evidence which he may desperately need. See 8 WIGMIORE, EvideNCE $\$ 2338$, at 666 (MINaughton rev. 1961).

56 Cf. Ayres v. State, 105 Tex. Crim. 15, 284 S.W. 960 (1926).

5767 N.M. 241, 354 P.2d 533 (1960).

58 N.M. Stat. ANn. § 41-12-19 (1953).

59 N.M. Stat, ANN. \$ 40A-1-12 (Supp. 1964). Curiously, the language of the statute is framed in terms of the incompetency of a spouse to testify, but the court spoke of a 
No reason was given by the lower court for its action in denying severance, but if the decision was based on any concern for expediency or convenience of prosecution, these matters are subservient to the important inquiry: Whether a separate trial will assist or impede the proper administration of justice and secure to the accused the rights of a fair trial. ${ }^{60}$

On balance, severance seems to be the best solution. Unlike any of the rules of limited dissolution of the husband's privileges, severance poses no threat that an innocent wife might be indicted with her suspected criminal husband merely for the sake of prosecutorial convenience. Unlike the Wigmore approach, severance poses no serious problem to the trial judge in that if the judge, in close cases, opts for severance, his decision is unlikely to be reversed. Furthermore, the added costs of separate trials are unlikely to be higher than the costs of new trials which would result from the practical difficulty of the trial judge's deciding whether a Wigmore-type rule should apply. If severance, like the rules of limited dissolution, is permitted to operate so as to allow the disclosure of confidential communications between the spouses which might better be kept secret, such testimony would still be less threatening to the stability and harmony of a marriage at a separate trial than at a joint trial because the testimony would be likely to have no direct effect upon the husband's fate.

Thus, severance seems preferable to the use alone of any of the available rules of limited dissolution of the husband's exclusionary privileges. It is also preferable to the use of curative instructions in states retaining either or both of the husband's privileges; in those states severance should be granted automatically upon the motion of either codefendant spouse. Denial of the husband's exclusionary privileges would probably constitute prejudicial error. ${ }^{61}$ But the granting of either privilege would result in a denial of the wife's right to speak in her own behalf and would also be grounds for reversal on appeal. Severance therefore leaves undisturbed the interests protected by the privileges, removes conspicuous grounds for reversal on appeal, and provides a full and fair hearing to both husband and wife.

right to exclude testimony, citing Hawkins v. United States, 358 U.S. 74 (1958), which spoke of a privilege. This is a typical example of the blurring of the various formulations regarding marital testimony restrictions which tends to confuse the whole area.

6067 N.M. 241, 247, 354 P.2d 533, 538 (1960).

61 But see People v. Bartell, 386 Ill. 483, 54 N.E.2d 700 (1944), where the other evidence was so conclusive against the defendant that the admission of testimony by his wife as to a confidential communication to her was held harmless error. 